\title{
Research of Composition and Properties of Pumpkin Pomace as Functional Food Ingredient
}

\author{
N M Derkanosova \\ Vice-Rector for Academic Affairs \\ Voronezh State Agrarian University named after the \\ Emperor Peter the Great \\ Voronezh, Russia \\ e-mail: kommerce05@list.ru \\ O V Peregonchaya \\ Associate professor of Department of Chemistry \\ Voronezh State Agrarian University named after the \\ Emperor Peter the Great \\ Voronezh, Russia \\ e-mail: ovp177@yandex.ru
}

\section{I Zajceva}

Department of Commodity Science and Expertise of Goods Voronezh State Agrarian University named after the Emperor Peter the Great

Voronezh, Russia

e-mail: fuchigi@mail.ru

\author{
O A Vasilenko \\ Department of Commodity Science and Expertise of Goods \\ Voronezh State Agrarian University named after the \\ Emperor Peter the Great \\ Voronezh, Russia \\ e-mail: ewa007@yandex.ru
}

\section{S A Sokolova}

Associate professor of Department of Chemistry Voronezh State Agrarian University named after the

Emperor Peter the Great

Voronezh, Russia

e-mail: chem@technology.vsau.ru

\author{
I N Ponomareva \\ Department of Commodity Science and Expertise of Goods \\ Voronezh State Agrarian University named after the \\ Emperor Peter the Great \\ Voronezh, Russia \\ e-mail: niirab@yandex.ru
}

\author{
S A Shelamova \\ Department of Commodity Science and Expertise of Goods \\ Voronezh State Agrarian University named after the Emperor Peter the Great \\ Voronezh, Russia \\ e-mail: shelam@mail.ru
}

\begin{abstract}
Food fibers are considered as nutrients, deficiency of which in a diet is pointed out in numerous studies. It is recommended to introduce both raw materials rich in cellulose, pectin, hemicelluloses, and isolated dietary fibers in the formulation of food products as sources of food fiber. On the basis of studies of organoleptic, physicochemical, functional, and technological characteristics, it was proposed to use pomace of pulp of pumpkin, apples, and common quince as a source of food fiber, which are secondary products of the technology of directpressed juice. Qualitative determination of the composition of food fibers was carried out using the method of infrared adsorption spectroscopy. Based on the results of research, it was found that a basis of food fibers is formed by cellulose. At the same time, pectin substances and nitrogen-containing vitamins, amino acids and peptides are present in the composition of the pomace. With varying degrees of efficiency, food fibers from apples, common quince and pumpkin can act as phytosorbents of heavy metals and radioactive nuclides.
\end{abstract}

Keywords-food fibers, functional nutrition ingredient, pumpkin pomace, apple pomace, common quince pomace

\section{INTRODUCTION}

The matters of human diet fortification with functional food ingredients are rightfully considered as the priorities of the population's healthcare sphere. Based on the results of the analysis of the current nutritional status of the population, the dietary fibers are classified as the deficit nutrients $[1,2,3]$.

Lack of food fibers in human diet leads to reduction of human organism's resisting power to the impact of the environment, to certain disease development and pathoses such as adipositas, large intestine diseases, diabetes, atherosclerosis, ischemic heart disease, excessive consumption of animal fat and associated deficit of polyunsaturated fatty acids, insufficient consumption of native (animal) proteins. Due to this, the research aimed at development of technologies, improving the consumer performance of the food by means of adding food ingredients rich in food fibers or isolated food fibers, is considered to be the priority tasks $[4,5,6]$. 


\section{OBJECTS AND METHODS OF THE RESEARCH}

The research supposed using the pomace of pumpkin (variety Muskatnaya), apples (variety Antonovka), common quince (variety Belorusskaya) as the source of food fibers which were obtained by means of convective drying to moisture content of $6 \%$ under the temperature below $50{ }^{\circ} \mathrm{C}$ in the vacuum evaporation station designed by professor A.A. Emelyanov [7, 8]. The pomace is the secondary product of the technology of directly squeezed juice production.

The features and composition of the pomace of Muskatnaya Antonovka apples and Belorusskaya common quince pumpkin were studied for assessment of the prospects of their use.

Physicochemical and microbiological indicators of pomace were determined by means of standardized methods.

Functional and technological properties of pomace were determined using the methods stated in $[15,16]$.

The research of the qualitative composition of the food fibers was performed using the method of adsorptive infrared spectroscopy employing the equipment of the Shared knowledge center of Voronezh state university.

Infrared spectroscopy is an analysis tool based on the study of interaction of a substance with the infrared region of electromagnetic spectrum $\left(4000-400 \mathrm{~cm}^{-1}\right)$. Infrared-Fourier spectroscopy is one of the most promising methods for studying complex multi-element compositions which allows detection of the structural analysis, microanalysis, and sample surface analysis and obtaining the information concerning functional groups within the molecule, their type, interactions and orientations $[9,10,11]$.

Infrared absorption spectra in the interval from 400 to $4000 \mathrm{~cm}^{-1}$ are obtained from IR-Fourier unit * Bruker VERTEX 70 in reflection mode. The samples had been dried before measuring to a constant weight under the temperature of $35^{\circ} \mathrm{C}$.

\section{RESEARCH RESULTS}

Dried pumpkin pomace is a dry fine cohesive product without blobs, cream-orange in colour, sweet, with pumpkin taste and flavour. Apple pomace is cream-coloured substance of sour-sweetish taste and smell typical for apples. Common quince pomace is cream-brown in colour with astringent aftertaste of common quince [12]. Sample characteristics of the pomace types are shown in table 1 .

As it was demonstrated by the research results, pumpkin, apple, and common quince pomace are characterized by low moisture content, good free-running properties, taste and flavor typical for fruit and vegetable raw materials. This proves their processability from the point of view of transportation and precious dozing as well as absence of negative effect on the organoleptic properties of the finished products.

The technology features determine sufficient concentration of cellulose, calcium, and vitamins in the food fibers [13]. It is especially essential taking into account their prospective use as the fortification raw material for flour confectionery production.

According to the research results, pumpkin pomace may be classified as food fibers or by-products of herbal raw material processing containing up to $30 \%$ of food fiber, while dried apple and common quince pomace are semi-concentrates with a food fiber share of $30-60 \%$. Henceforth in this article, the term "food fiber" is applied for dried pomace.

TABLE I. QUALITY INDICATORS OF DRIED POMACE

\begin{tabular}{|c|c|c|c|}
\hline Indicator & $\begin{array}{c}\text { Dried } \\
\text { pumpkin } \\
\text { pomace }\end{array}$ & $\begin{array}{c}\text { Dried apple } \\
\text { pomace }\end{array}$ & $\begin{array}{l}\text { Dried common } \\
\text { quince pomace }\end{array}$ \\
\hline Moisture content, $\%$ & $5.3 \pm 0.65$ & $5.5 \pm 0.65$ & $5.7 \pm 0.65$ \\
\hline $\begin{array}{c}\text { Concentration, } \% \text { of } \\
\text { dry weight, of } \\
\text { cellulose }\end{array}$ & $19.6 \pm 0.98$ & $14.3 \pm 0.76$ & $22.6 \pm 0.68$ \\
\hline hemicellulose & $3.5 \pm 0.14$ & $14.3 \pm 0.57$ & $4.7 \pm 0.19$ \\
\hline pectin & $5.4 \pm 0.22$ & $13.9 \pm 0.56$ & $11.4 \pm 0.46$ \\
\hline $\begin{array}{c}\text { Mass content, mg/100 } \\
\mathrm{g} \\
\text { Calcium } \\
\text { Phosphorus }\end{array}$ & $\begin{array}{c}90 \pm 3.6 \\
14 \pm 0.56\end{array}$ & $\begin{array}{c}160 \pm 6.4 \\
40 \pm 1.6\end{array}$ & $\begin{array}{l}200 \pm 8.0 \\
23 \pm 0.92\end{array}$ \\
\hline Bulk density, $\mathrm{kg} / \mathrm{m}^{3}$ & $640 \pm 25.6$ & $670 \pm 26.8$ & $645 \pm 25.8$ \\
\hline \multicolumn{4}{|c|}{ Mesh-size distribution, $\%$} \\
\hline $\begin{array}{l}\text { particle size from } 125 \\
\text { to } 315 \mathrm{mcm}\end{array}$ & $48.2 \pm 1.9$ & $41.6 \pm 1.7$ & $51.0 \pm 2.04$ \\
\hline $\begin{array}{l}\text { particle size from } 63 \text { to } \\
125 \mathrm{mcm}\end{array}$ & $47.5 \pm 1.9$ & $51.8 \pm 2.07$ & $45.2 \pm 1.8$ \\
\hline $\begin{array}{l}\text { particle size less than } \\
63 \mathrm{mcm}\end{array}$ & $4.3 \pm 0.17$ & $6.6 \pm 0.26$ & $3.8 \pm 0.15$ \\
\hline
\end{tabular}

From the point of view of technologies for the use of food fibers, their functional and technological properties were studied: fat and water binding capacity, solubility. The studies took into account not only the origin of the food fibers, but their mesh-size distribution, the effect of temperature and active acidity of the medium.

Each of the studied functional and technological features possesses its certain value for flour confectionery production.

Fats inserted in the dough during kneading are bound with proteins, starch and probably with other solid components. Part of the fat may be present as emulsion in the dough liquid phase, which considerably affects the dough rheological behaviour and, accordingly, baking capacity of the flour and product quality.

The results of study of mesh-size distribution impact on fat-binding capacity of food fibers of different origin are shown in Fig. 1.

As it is shown by the research results, the concentrate of dietary fibers from common quince possesses the most fatbinding ability. The results correlate with the data about the chemical composition of the food fiber. The common quince product has the highest content of fiber possessing sorption capacity among the samples studied. Apparently, complexes of lipids and food fibers are formed there. 


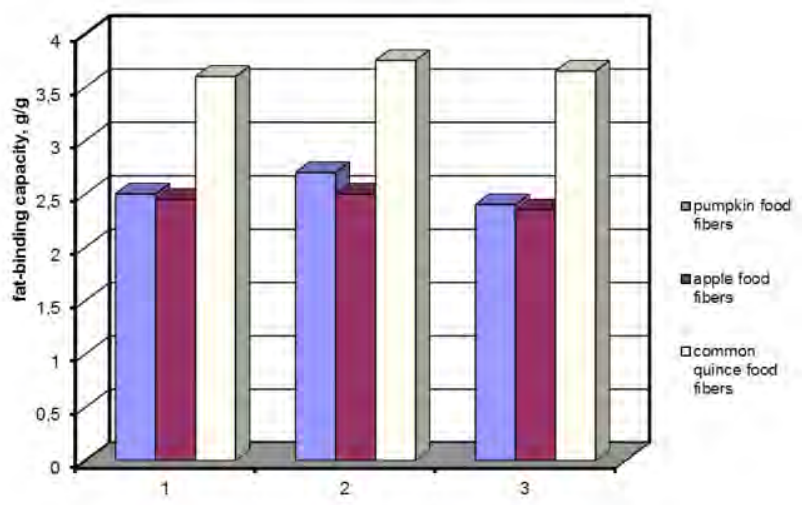

Fig. 1. Fat-binding capacity of food fibers with mesh-size distribution: $1-$ from 125 to $315 \mathrm{mcm}, 2$ - from 63 to $125 \mathrm{mcm} ; 3$ - less than $63 \mathrm{mcm}$

As for the impact of the mesh-size distribution on the fatbinding ability, here we should note that the following regularity remains in place for all three samples. The best fatbinding ability is the characteristic of the food fibers reduced to the particle size from 63 to $125 \mathrm{mcm}$. Further pounding apparently leads to fat sorption reduction at the inner surfaces of the porous product due to decrease of the area of those surfaces.

Water-binding capacity is equally important quality parameter of the raw materials. High hydrophility may affect rheological behaviour of the semi-products and finished product quality. In respect to food fibers, it can also be of certain importance improving intestinal mobility and reducing the period of transit through the digestive tract.

The results of study of mesh-size distribution impact on water-binding capacity of food fibers of different origin are shown in Fig. 2.

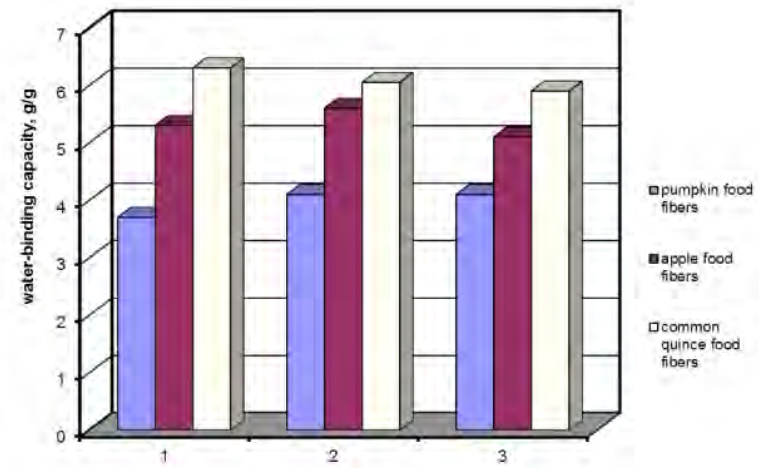

Fig. 2. Water-binding capacity of food fibers with mesh-size distribution: 1 - from 125 to $315 \mathrm{mcm}, 2$ - from 63 to $125 \mathrm{mcm} ; 3$ - less than $63 \mathrm{mcm}$

In forming the properties of the dough and, accordingly, the finished products, one of the main factors is the ability of its components to bind and retain water, as well as to pass into the solution. It is known that in the dough there is liquid along with the solid phase. With regard to water not bound through adsorption by starch proteins, there are water-soluble substances in the solution, which have significant effect on the structural and mechanical properties of the dough and the intensity of the biochemical and microbiological processes of its maturation.

The results of study of mesh-size distribution impact on solubility of food fibers of different origin are shown in Fig. 3.

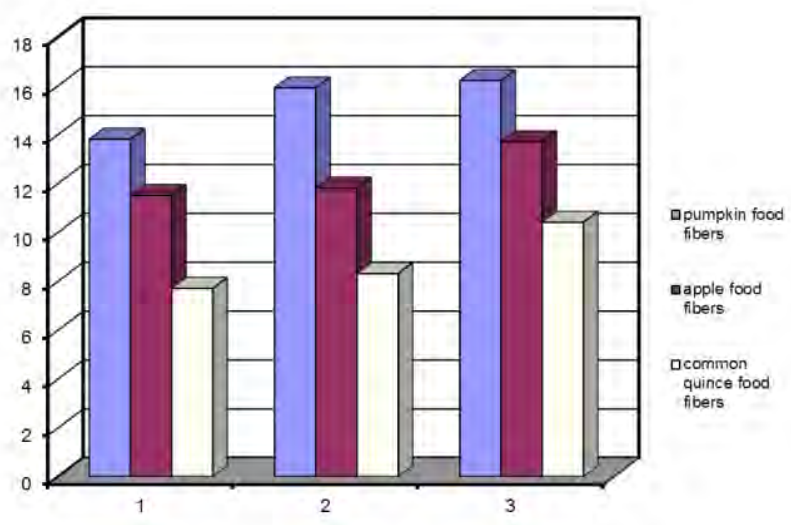

Fig. 3. Solubility of food fibers with mesh-size distribution: 1 - from 125 to $315 \mathrm{mcm}, 2-$ from 63 to $125 \mathrm{mcm} ; 3$ - less than $63 \mathrm{mcm}$ )

According to the research results pomace solubility does not depend on mesh-size distribution. Within the studied conditions for obtaining samples, mechanical effects do not affect the structure of the biopolymers of the product and, accordingly, only the initial water-soluble substances pass into the solution. At the same time, solubility depends on the origin of the source of raw materials. The maximum amount of water-soluble substances is contained in food fibers from pumpkin, which makes it possible to recommend this semifinished product as a component that intensifies the processes of maturing of semi-finished products and dough.

To assess the prospects for using food fiber as a functional food ingredient, its qualitative composition was studied. Figure 4 represents spectral features of the food fiber samples (graphs 1-3) and cellulose (graph 4).

The comparison of spectral features (fig., graphs 1-4) proves that the basis of the food fibers is formed of cellulose.

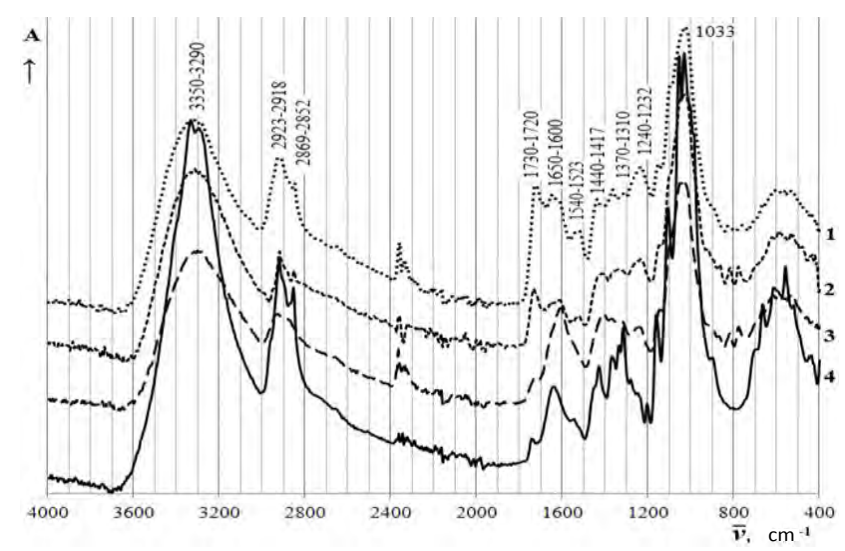

Fig. 4. Infrared absorption spectra (A) for food fiber samples: 1 - common quince, 2 - apple, 3 - pumpkin; 4 - cellulose fiber 
We obtained similar data from the studied comparative composition of apple, common quince, and pumpkin pomace were performed using the quantitative methods mentioned above. There are intensive absorption lines $2923-2918 \mathrm{~cm}^{-1}$, 2869-2852 cm-1, 1440-1200 $\mathrm{cm}^{-1}$ in IR spectra for all samples describing stretch vibrations of $\mathrm{C}-\mathrm{H}$ in the methylene fragment $[11,13,14,15]$. Stretch vibrations in polar group C-O-C, found in aliphatic ester groups, manifest themselves in spectra as a pronounced peak at $1033 \mathrm{~cm}^{-1}$ with lines 1150 and 900 $\mathrm{cm}-1$ at the maximum base $[11,13]$. All samples demonstrate the presence of hydroxyl groups in their structure which are the elements of the secondary alcohols; and in samples 1 and 2 they are also found in carboxyl groups. It is proven by wide clear line observed in all spectrograms in the interval of 3400$3200 \mathrm{~cm}^{-1}$, corresponding stretch vibrations of atoms $\mathrm{O}-\mathrm{H}$, participating in formation of intra- and intermolecular hydrogen bonds, as well as stretch vibrations of N-H bonds $[11,13,14,15]$. Absorption lines 1440-1417, $1370-1310 \mathrm{~cm}^{-1}$, corresponding the deformation vibrations of $-\mathrm{OH}$ group, are present in all spectrograms, but are most clear in cellulose spectrum. Presence of carboxyl groups allows a suggestion concerning participation of biopolymers of the pomace in the process of heavy metal and radioactive nuclide elimination. Besides, general positive effect of cellulose on the digestive tract performance is commonly observed.

To a greater extent, the functions of phytosorbent are typical of pectin substances. The changes observed in the spectra of food fibers in the area of $1800-1200 \mathrm{~cm}^{-1}$ relative to cellulose are associated with the presence of pectic substances and nitrogen-containing vitamins, amino acids and peptides. The previous studies of the composition of food fibers confirmed the dependencies shown in the figure. Apple and common quince pomace is described by almost twice higher pectin content compared to pumpkin. Elemental analysis using Kjeldahl method showed nitrogen presence of 2.11 mass $\%$ for pumpkin food fiber, 1.69 mass \% for common quince, and 0.73 mass $\%$ for apple.

There are pronounced peaks of $1720 \mathrm{~cm}^{-1}$ for common quince and $1730 \mathrm{~cm}^{-1}$ for apple and pumpkin in the spectrograms, which are associated with vibrations of $\mathrm{C}=\mathrm{O}$ within $-\mathrm{COOH}$ group. Displacement of this maximum by 10 $20 \mathrm{~cm}^{-1}$ in the direction of low-frequency region compared to cellulose spectrum $\left(1740 \mathrm{~cm}^{-1}\right)$ indicates association of carboxyl groups and formation of dimeric polymers most typical for sample 1. Presence of salt form of carboxyl group especially clear in sample 3 can be explained by higher $\mathrm{pH}$ value in the process of food fiber production and is proven by presence of adsorption at $1650-1610 \mathrm{~cm}^{-1}$ [10]. Presence of amide and peptide bonds of albuminous compounds is in the sample composition in $\mathrm{C}-\mathrm{N}$ and $\mathrm{N}-\mathrm{H}$ vibration regions. For example, line $1240-1232 \mathrm{~cm}^{-1}$ (fig.1, graphs 1-3), according to [10], may be attributed to stretch vibrations of the carbonyl group $(\mathrm{C}=\mathrm{O})$ in the composition of alcohol esters, as well as skeletal vibrations in presence of $\mathrm{C}-\mathrm{N}$ bond within the composition of amide bonds $\mathrm{C}(\mathrm{O})-\mathrm{NH}[8,9]$. At the same time, in samples 1 and 2 presence of deformation vibrations of $\mathrm{N}-\mathrm{H}$ is observed in both primary and secondary amide bonds (1643-1600 $\left.\mathrm{cm}^{-1}, 1540-1523 \mathrm{~cm}^{-1}\right)$, while for sample 3 only presence of primary amide bonds $\left(1600 \mathrm{~cm}^{-1}\right)$ is typical
$[11,12]$. It is important from the point of view of formation of organoleptic characteristics of baked convenience foods and ready-made bakery or flour confectionery, as it is the reaction of melanoidin formation that determines the golden yellow color of the product surface.

One of the most important factors assessed during introduction of a new raw material ingredient in food technology is its microbiological safety.

The results of the research of microbiological indicators of food fibers of Muskatnaya pumpkin are demonstrated in Table 2 .

TABLE II. MICROBIOLOGICAL INDICATORS OF FOOD FIBERS

\begin{tabular}{|c|c|}
\hline Indicators & $\begin{array}{c}\text { Microbiological features of } \\
\text { pumpkin food fibers, CFU/g }\end{array}$ \\
\hline $\begin{array}{c}\text { The quantity of mesophilic } \\
\text { aerobic and optionally anaerobic } \\
\text { microorganisms (QMA\&OAMO) }\end{array}$ & $3.5 \times 10^{3}$ \\
\hline
\end{tabular}

The description of microorganism colonies in pumpkin food fibers is shown in Fig. 5 and Table 3.

TABLE III. CULTURAL PROPERTIES OF THE MICROORGANISMS DETECTED

\begin{tabular}{|c|c|c|}
\hline $\begin{array}{c}\text { Number } \\
\text { of } \\
\text { colonies }\end{array}$ & Cultural properties & Morphology markings \\
\hline 3.5 & $\begin{array}{c}\text { Colony size is 10 mm with } \\
\text { diffusive undulating edge size of 3 } \\
\text { mm, milky colour, opaque with } \\
\text { smooth glossy surface. Soft } \\
\text { texture. }\end{array}$ & $\begin{array}{c}\text { Bacteria are rod bacteria, } \\
\text { nonmotile, } \\
\text { nonsporulating, variable } \\
\text { length, allocation is } \\
\text { solitary or in pairs. }\end{array}$ \\
\hline & $\begin{array}{c}\text { Rectangular colony size of 38x } 55 \\
\text { mm, whitish-beige colour with } \\
\text { diffusive fringy whitish edge with } \\
\text { rough surface. Soft texture. }\end{array}$ & \\
\hline 1 & $\begin{array}{c}\text { Filamentous colony. White } \\
\text { mycelia, crawling, with radial } \\
\text { lines, yellow colour changing to } \\
\text { marshy-green during sporulation. } \\
\text { Black spores. }\end{array}$ & Microfungus, genus \\
& Aspergillus. \\
\hline
\end{tabular}
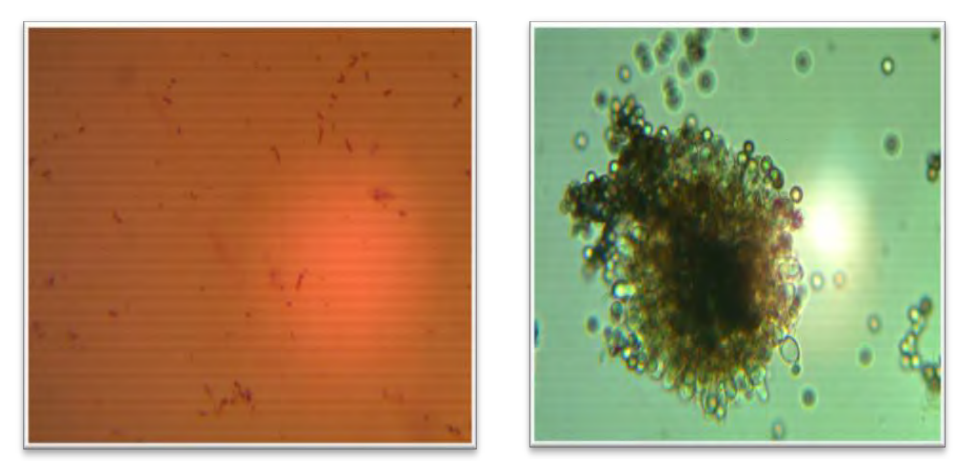

Fig. 5. The results of microbiological study of Muskatnaya pumpkin food fibers 
Analysis of the requirements set in TR TS 021/2011 "Concerning food product safety" for the products closest to the research object (dehydrofrozen vegetable powders, grain food boltings; bolting food fibers) demonstrated microbiological safety of the food fibers obtained from Muskatnaya pumpkin.

The obtained results prove practicability of using dried Muskatnaya pumpkin pomace as the fortification raw material ingredient for the flour confectionery production process.

\section{SUMMARY}

The performed studies of the composition of food fibers obtained by low-temperature drying of the pomace of direct pressing juice of apples, common quince and pumpkin, using the method of infrared adsorption spectroscopy, allow the following conclusions

- the basis of food fibers consists of cellulose;

- the maximum content of food fibers is typical for common quince pomace;

- the changes observed in the food fiber spectra compared to cellulose are associated with the presence of pectic substances and nitrogen-containing vitamins, amino acids and peptides;

- apple and common quince pomace is described by high concentration of pectic substances;

- apple, common quince, and pumpkin food fibers may act as phytosorbents for heavy metals and radioactive nuclides but with various degrees of efficiency;

- from the point of view of formation of organoleptic characteristics of baked convenience foods and flour confectionery the pomace made of pumpkin variety Muskatnaya is preferable.

\section{References}

[1] V.I.Pokrovskiy, G.A.Romanenko, V.A.Knyazhev, N.I.Gerasimenko, G.G.Onischenko, V.A.Tutelyan, and V.M.Poznyakovskiy, Healthy diet policy: National and regional levels, Novosibirsk:Siberian University Publishing, 2002
[2] Yu.G.Guryanov and V.M.Poznyakovskiy, Innovative products for healthy diet based on local raw materials, KemerovoЖ, Kuzbassvuzizdat, 2013

[3] M.P. Mogilnyy. T.V. Shlenskaya. M.K. Galyukova. T.Sh. Shaltumayev. A.Yu. Balasyan, "Modern trends in the use of dietary fibers as functional ingredients", New technology, vol.1, pp. 27-31, 2013

[4] N.M. Marina, G.N. Novoselova, and S.A.Shavnin, "Products of the improved biological value made of unorthodox herbal raw materials", Bulletin of Samara scientific center of Russian Academy of Science, vol.12, no.1(8), 2010, pp.2079-2082

[5] E.I.Scherbakova, "Development of the technology for bakery confectionary products using the new types of raw materials", Bulletin of YuUrGU, 2014, vol. 2, no. 4, pp.85-90.

[6] N. M. Derkanosova, S. A. Shelamova, I. N. Ponomareva, G. V Shurshikova, O. A. Vasilenko "Parameters modelling of amaranth grain processing technology", IOP Conf. Series: Materials Science and Engineering, vol 327, no. 020023, December 2017 [International Conference on Mechanical Engineering, Automation and Control Systems 2017, p. 583, 2018].

[7] A.A.Emelyanov and E.A.Kuznetsova, "Pumpkin pulp components", Beer and beverages, vol.4, pp. 40-43, 2009.

[8] Ma Meng-mei, Mu Tai-hua, "Effects of extraction methods and particle size distribution on the structural, physicochemical, and functiona properties of dietary fiber from deoiled cumin", Food Chemistry, vol.194, pp. 237-246, 2016

[9] Z-L. Huang, Z-Y. Liang, G-J. Li, H. Hong, "Response surface methodology to extraction of dioscoreae polysaccharides and the effects on rat's bone quality", Carbohydrate Polymers, vol.83, pp. 32-37, 2011

[10] L.A.Kazitsyna, N.B.Kupletskaya, Application of UV-, IR-, NMR-, and mass-spectrometry in organic chemistry, Moscow: Moscow university press, 1979

[11] N.M. Derkanosova, I.I. Zaytseva, E.A. Laptieva, and A.A. Emelyanova "Study of the functional and technological features of fruit and vegetable pomace for bakery product formtification", Bakery products, vol.4, pp. 44-46, 2016

[12] B.N. Tarasevich, IR spectra for the main classes of organiza compositions. Reference materials', Moscow: Moscow state university publishing, 2012.

[13] M. Otto, Contemporary methods of analytic chemistry, Vol.1, Moscow: Tekhnosfera, 2003.

[14] N.G. Bazarnova, E.V.Karpova, I.B.Katrakov et.al., The research methods for timber and its products, Barnaul: Altay state university publishing, 2002.

[15] V.V. Kolpakova, A.E. Volkova, A.P. Nechaev, "Emulsifying and foaming properties of protein flour made of wheat middling", Bulletin of higher education institutions on Food technology, vol.1-2, pp. 34-37, 1995

[16] V.V.Kolpakova and A.P.Nechaev, "Solubility and water-binding capacity of protein flour made of wheat middling", Food technology, vol.1-2, pp. 31-33, 1995 